\title{
The Selection of Dry Port Location by Analytic Network Process Model: A Case Study of Dosso-Niger
}

\author{
Hamadou Tahirou Abdoulkarim ${ }^{1 *}$, Seydou Harouna Fatouma ${ }^{2}$, Bomboma Kalgora1 \\ ${ }^{1}$ School of Economics \& Management, Shanghai Maritine University, Shanghai, China \\ ${ }^{2}$ Glorious Sun School of Business and Management, Donghua University, Shanghai, China \\ Email: *kalishufe@hotmail.com
}

How to cite this paper: Abdoulkarim, H.T., Fatouma, S.H. and Kalgora, B. (2019) The Selection of Dry Port Location by Analytic Network Process Model: A Case Study of Dosso-Niger. Journal of Transportation Technologies, 9, 146-155. https://doi.org/10.4236/jtts.2019.92009

Received: February 14, 2019

Accepted: March 17, 2019

Published: March 20, 2019

Copyright $\odot 2019$ by author(s) and Scientific Research Publishing Inc. This work is licensed under the Creative Commons Attribution International License (CC BY 4.0). http://creativecommons.org/licenses/by/4.0/

\begin{abstract}
The aim of this paper is to select the best location for the construction of a dry port in Niger which is a land locked country (LLC). Niger is located in the Sahel and has a land area of 1,267,000 square kilometers [1], with the closest port being port of Cotonou in Benin. The transport corridor from Niamey to Cotonou is approximately $1036 \mathrm{~km}$ long [2]. It is estimated that this corridor carries about 40 percent of Niger's overseas trade traffic [3]. In this work, the Analytic Network Process (ANP) model is used to determine the optimal location of the dry port, among three major cities: Niamey (capital city), Dosso and Gaya. From the application of this selection model, Dosso was selected as the best location for the location of the dry port, while Gaya and Niamey were placed second and third respectively. The results obtained in this work strongly confirm the decision of the government of Niger to construct a dry port in Dosso, a project that commenced in 2010 and is still in progress.
\end{abstract}

\section{Keywords}

Dry Port, Localization, Analytic Network Process (ANP) Model

\section{Introduction}

The Port of Cotonou is an important regional port. Over $80 \%$ of all goods entering the Port of Cotonou are destined for regions outside Benin, with Niger and Nigeria accounting for about 90 percent of Cotonou's transit and re-export traffic [4]. In order to improve the performance of transport corridors' logistic systems, most land locked countries are developing intermodal terminals commonly referred to as dry ports. Being an LLC in West Africa, Niger would im- 
mensely benefit from a dry port facility. Consequently, plans to construct such a facility in Niger were started and Dosso, Niamey and Gaya were proposed as the three possible locations for the development of this invaluable facility and the most suitable one among these locations was to be selected. Dosso was chosen as the most suitable location for this project. This town is $136 \mathrm{~km}$ from Niamey, the capital city of Niger, on the Cotonou transport corridor and $462 \mathrm{~km}$ from the rail head at Parakou. The dry port was proposed as a Greenfield development at the junction of the main routes to Cotonou and also to Zinder which is the second largest city in Niger. After completion, this project is expected to achieve the following objectives:

1) To facilitate and process international trade goods for Niger and promote value-added services as goods move through the supply chain.

2) To speed up the flow of cargo between the port and major land transportation networks.

3) To move the time-consuming activities (sorting and processing) of merchandise inland, away from the congested port of Cotonou.

The dry port is to be constructed using a public private partnership (PPP) development model and will provide customs clearance and processing services.

Choosing the most ideal location for the construction of a dry port requires careful considerations to be made and as such analytical tools have been developed to aid in making the best choice of locating such a facility. Although Dosso was chosen as the best location for the development of the dry port, this paper will endeavor to compare the suitability of the three initial proposed locations and provide analytical justification for the choice of the suitable location for this project. Under the current plan of having the dry port constructed at Dosso, cargo would be transferred from rail to truck at Parakou and again at Dosso. Studies have shown that the majority of cargo that move along the corridor the Cotonou transport corridor is destined for Niamey and this could make it the ideal location for the facility. The other possible location for the location of the dry port is at the border town of Gaya. The town is at the junction of the corridor to Cotonou and Nigeria through the border post at Kamba. This adds up to the complexity of selecting the ideal location for the dry port. The dry port location is also proposed in a region where there are other dry port projects such as at the Northern part of Nigeria, Burkina Faso and Mali.

A railway line has been proposed, which may help to address the perennial underinvestment in the transport system, although it is not apparent what value the railway would add at Parakou, besides being a convenient customs clearance point. Moreover, there has been discussion to extend the railway to Niamey which would possibly overcome the necessity for increased cargo handling. Although Dosso was selected as the most suitable location for the construction of the dry port amongst the three proposed towns, there exist no analytical justification for this decision in literature and that is what this study will aim to achieve. In addition, it will provide a basis for future selection of dry port selec- 
tion, not only in Niger but also for the other countries in the region that would wish to construct similar facilities.

\section{Literature Review}

Over the past ten years, a vast literature reviews and several models have been used by researchers to solve the problem of determining the best location for dry port construction. There are differences in dry ports according to their geographical location. Woxenius et al. (2004) [5] and Roso et al. (2009) [6] have classified three different kinds of dry ports: close dry ports, mid-range dry ports and distant dry ports, according to their functions and distances from the seaport.

West Africa seaports lack a good cooperation with gateway seaports. This has resulted in the perennial high logistics cost occasioned by the difference in distances between economic zones and the seaports. This has led to high greenhouse gasses emissions (carbon dioxide), noise, and frequent road accidents by trucks hauling cargo to the far hinterlands, (Henttu, Lättiläl, and Hilmola, 2010) [7]. Users of the seaport are free to select the one that meets their needs, based on a trade-off concept, where the choice is made between cost and service level according to (van Dyck and Domfeh, 2017) [8]. Therefore, the argument is that, there is a difference in motivation to the development of dry port based on developed and underdeveloped systems ( $\mathrm{Ng} \&$ Gujar, 2009) [9]. In this study, we indicate that dry ports are not located in the production zones, but rather in major market centers, for this case the selected possible locations, that is, Dosso, Niamey and Gaya. These market centers are the economic zones of the case study in this current work. Due to the difference in distance from the gateway seaports and the hinterlands, there is high logistics cost and shippers tend to choose the port the most suitable sea port among the main ports along the West African coast line of Tema, Lome, Cotonou, Dakar, Abidjan among others, based on the distance, cost and quality of service offered. These ports are also congested and hence a dry port far away from the sea ports into the hinterland would help in decongesting the sea ports as well as improving service delivery to the shippers and consumers in Niger (H. T. Abdoulkarim et al., 2019) [10].

\section{Methodology and Results}

Analytic Network Process (ANP) was proposed by Saaty [11]. The ANP is an all-inclusive decision-making method that has the proficiency to take account of all relevant criteria, in determining a decision. It is an extension of Analytic Hierarchical Process (AHP) model which adopts a decision-making framework that shoulders an un-directional hierarchical relationship among decision stages. According to Saaty [12] AHP can help solve complex Multi Criteria Decision Making (MCDM) problems, with a low rate of success when applied to problems involving multi-criteria or hierarchy dependent relationships [13].

Accordingly, Saaty again advances a new theory, which maintains the spirit of 
AHP and continues developing the ANP method, inspiring the analytical ability of ANP. More often than not, interdependence exists among criteria and alternatives applied in making a decision. In view of this, the ANP model provides an effective tool in cases where interactions among the elements of a system form a network structure through a super matrix methodology [14].

The effectiveness of the model has led to its application over decades across the globe. In addition, due to its structural content, it can be applied in every discipline as it has been expression by a number of researchers. Lee and Kim [15] used ANP for information system project selection. Cheng and Li [16] applied ANP in selecting a contractor. Moreover, Poonikom et al. [17] adopted ANP in making decisions for university selection. To select logistics service providers, Jharkharia and Shankar [18] successfully used ANP model. To this end, it can be seen that ANP is a versatile model which can be successfully used in a wide range of multi-criteria decision making applications.

The proposed ANP model is applied in four steps through which the relative weights of the criteria are determined [19]. The alternatives are then ranked and the optimal dry port location is selected by use of Super Decision software. These steps are detailed as follows:

\section{Step 1: Establishing a hierarchical structure of the ANP network}

The problem of selecting the dry port location is grouped into four stages: 1) achieving the ultimate goal of selecting the optimal dry port location, 2) 3 criteria, 3) 9 sub-criteria, and 4) 3 alternatives. Table 1 and Figure 1 illustrate the grouping of the main stages in the selection process [20].

\section{Step 2: Determining the interdependency among criteria}

Figure 2 and Figure 3 show the interdependence among different criteria based on the hierarchical structure.

A questionnaire with 22 questions in tabular format was sent out to experts to score the specified criteria through pair-wise comparison. A total of fifteen experts consisting of five operators, five users and five community representatives were requested to make the pair-wise comparison of the decision criteria and assign relative scores. The results of the consistency test; the Consistency Ratio (CR) of the comparison matrix from each of the fifteen experts, were all less than 0.1 , indicating consistency in the responses. In addition, the CR of the aggregate matrix was also below 0.1 , which further showed that the responses were consistent among the experts (Table 2).

\section{Step 3: Determine the weight of ANP and select the optimum}

Table 3 shows the alternatives that were fed through the system to give rise to the synthesized values, while Table 4 shows the ranking of the alternatives.

\section{Step 4: Determining the optimum location for the dry port}

As indicated in Table 4 the report shows that Dosso was found to be the ideal location for the construction of the dry port in Niger. It is consistent with the decision by the government of Niger to select Dosso as the most suitable location for the construction of a dry port facility (Figure 4). 
Table 1. Major criteria, sub-criteria and alternatives used in building the ANP network.

\begin{tabular}{cc}
\hline Clusters & Notation \\
\hline Major Criteria & Cost \\
& Demand \\
& Proximity (Distance) \\
Sub-Criteria Cost & Energy \\
& Labor \\
& Land \\
Sub-Criteria Demand & Transport \\
& Export \\
Sub-Criteria Proximity (Distance) & Import \\
& Highway/Railway \\
& Logistics Platforms (Seaports, ICDs) \\
& Market Centers \\
& Dosso \\
& Gaya \\
\end{tabular}

Table 2. The aggregate weighted super matrix after pair-wise comparison and consistency test.

\begin{tabular}{|c|c|c|c|c|c|c|c|c|c|c|c|c|c|c|c|c|}
\hline & Dosso & Gaya & Niamey & Energy & Labor & Land & Transport & Cost & Demand & $\begin{array}{l}\text { Proximity } \\
\text { (Distance) }\end{array}$ & Export & Import & $\begin{array}{c}\text { selection } \\
\text { of dry } \\
\text { port }\end{array}$ & $\begin{array}{l}\text { Highway/ } \\
\text { Railway }\end{array}$ & $\begin{array}{l}\text { Logistics } \\
\text { platforms }\end{array}$ & $\begin{array}{l}\text { Market } \\
\text { centers }\end{array}$ \\
\hline Dosso & 0 & 0 & 0 & 0.35231 & 0.4126 & 0.69424 & 0.29682 & 0.18614 & 0.23711 & 0.17167 & 0.3333 & 0.3333 & 0 & 0.1667 & 0.1667 & 0.1667 \\
\hline Gaya & 0 & 0 & 0 & 0.36183 & 0.25992 & 0.21025 & 0.12466 & 0.10654 & 0.1882 & 0.13792 & 0.3333 & 0.3333 & 0 & 0.1667 & 0.1667 & 0.1667 \\
\hline Niamey & 0 & 0 & 0 & 0.28586 & 0.32748 & 0.09551 & 0.07853 & 0.04065 & 0.07469 & 0.02374 & 0.3333 & 0.3333 & 0 & 0.1667 & 0.1667 & 0.1667 \\
\hline Energy & 0 & 0 & 0 & 0 & 0 & 0 & 0 & 0.17877 & 0 & 0 & 0 & 0 & 0 & 0 & 0 & 0 \\
\hline Labor & 0 & 0 & 0 & 0 & 0 & 0 & 0 & 0.09779 & 0 & 0 & 0 & 0 & 0 & 0 & 0 & 0 \\
\hline Land & 0 & 0 & 0 & 0 & 0 & 0 & 0 & 0.03548 & 0 & 0 & 0 & 0 & 0 & 0 & 0 & 0 \\
\hline Transport & 0 & 0 & 0 & 0 & 0 & 0 & 0 & 0.0213 & 0 & 0 & 0 & 0 & 0 & 0 & 0 & 0 \\
\hline Cost & 0 & 0 & 0 & 0 & 0 & 0 & & 0 & 0 & 0.16667 & 0 & 0 & 0.56954 & 0 & 0 & 0 \\
\hline Demand & 0 & 0 & 0 & 0 & 0 & 0 & 0 & 0.16667 & 0 & 0.16667 & 0 & 0 & 0.33307 & 0 & 0 & 0 \\
\hline $\begin{array}{l}\text { Proximity } \\
\text { (Distance) }\end{array}$ & 0 & 0 & 0 & 0 & 0 & 0 & 0 & 0.16667 & 0 & 0 & 0 & 0 & 0.09739 & 0 & 0 & 0 \\
\hline Export & 0 & 0 & 0 & 0 & 0 & 0 & 0.25 & 0 & 0.33333 & 0 & 0 & 0 & 0 & 0.25 & 0.25 & 0.25 \\
\hline Import & 0 & 0 & 0 & 0 & 0 & 0 & 0.25 & 0 & 0.16667 & 0 & 0 & 0 & 0 & 0.25 & 0.25 & 0.25 \\
\hline $\begin{array}{l}\text { Selection of } \\
\text { dry port }\end{array}$ & 0 & 0 & 0 & 0 & 0 & 0 & 0 & 0 & 0 & 0 & 0 & 0 & 0 & 0 & 0 & 0 \\
\hline $\begin{array}{l}\text { Highway/ } \\
\text { Railway }\end{array}$ & 0 & 0 & 0 & 0 & 0 & 0 & 0 & 0 & 0 & 0.20834 & 0 & 0 & 0 & 0 & 0 & 0 \\
\hline $\begin{array}{l}\text { Logistics } \\
\text { platforms }\end{array}$ & 0 & 0 & 0 & 0 & 0 & 0 & 0 & 0 & 0 & 0.0795 & 0 & 0 & 0 & 0 & 0 & 0 \\
\hline
\end{tabular}


Table 3. Synthesized values from alternatives.

\begin{tabular}{|c|c|c|}
\hline Priorities & & \\
\hline Name & Normalized by Cluster & Limiting \\
\hline Dosso & 0.35924 & 0.294632 \\
\hline Gaya & 0.33476 & 0.274554 \\
\hline Niamey & 0.306 & 0.250961 \\
\hline Energy & 0.53631 & 0.010376 \\
\hline Labor & 0.29338 & 0.005676 \\
\hline Land & 0.10642 & 0.002059 \\
\hline Transport & 0.06389 & 0.001236 \\
\hline Cost & 0.21547 & 0.007326 \\
\hline Demand & 0.5 & 0.017 \\
\hline Proximity (Distance) & 0.28453 & 0.009674 \\
\hline Export & 0.57599 & 0.064426 \\
\hline Import & 0.42401 & 0.047426 \\
\hline Selection of Dry Port Location for Niger & 0 & 0 \\
\hline Highway/Railway & 0.62503 & 0.009158 \\
\hline Logistics Platform & 0.23847 & 0.003494 \\
\hline Market Centers & 0.1365 & 0.002 \\
\hline
\end{tabular}

Table 4. Ranking of alternatives.

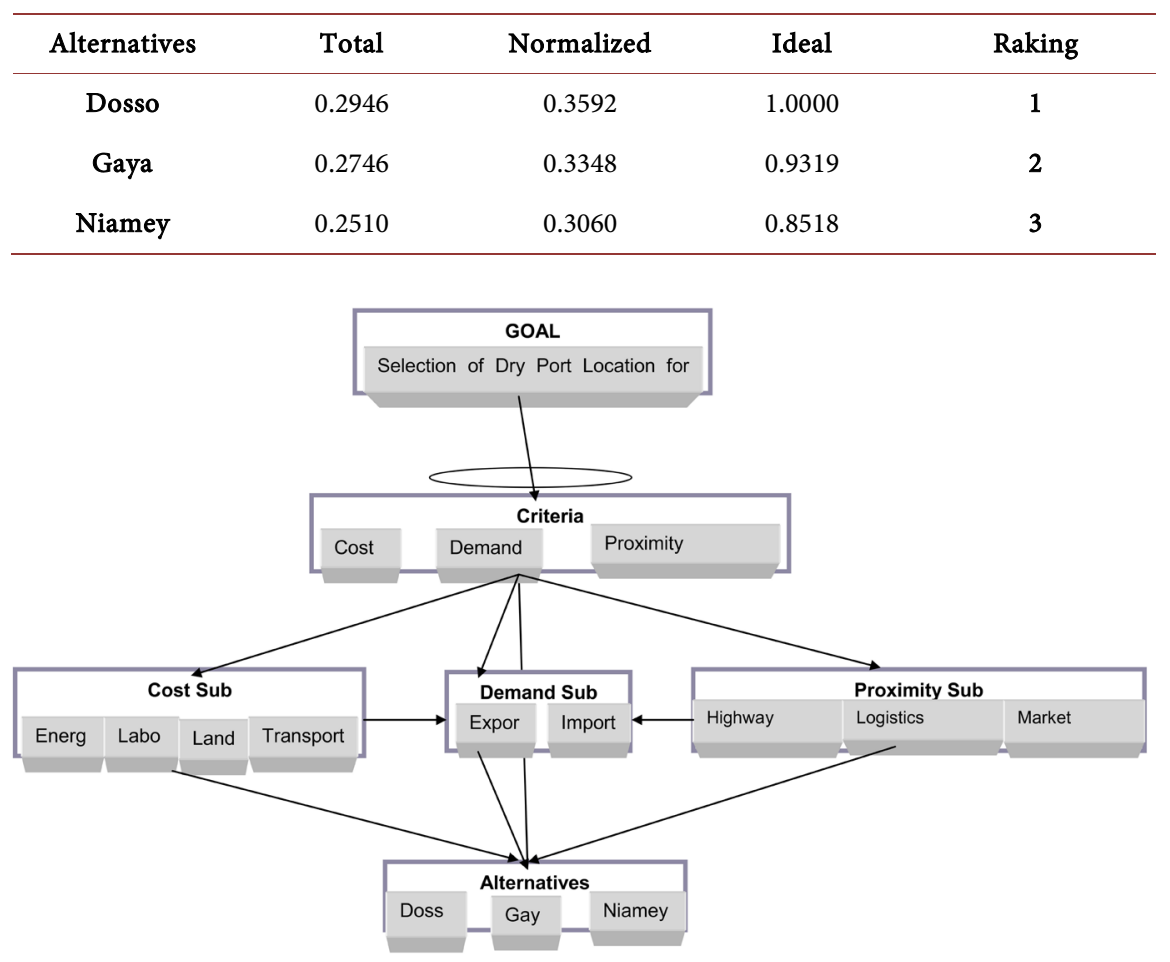

Figure 1. Analytical network process. 


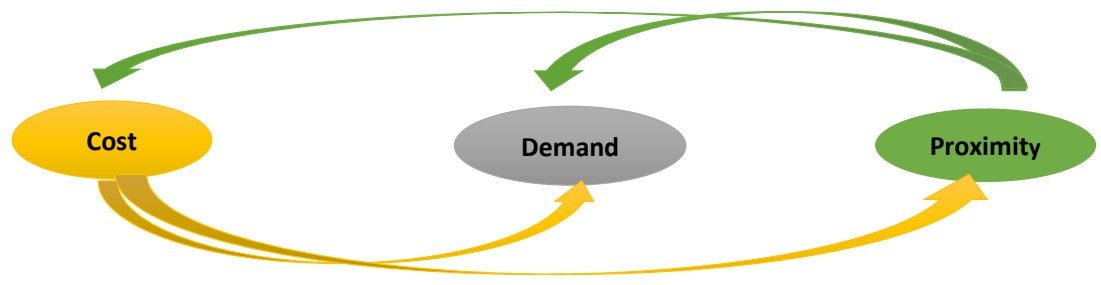

Figure 2. Major criteria interdependency.

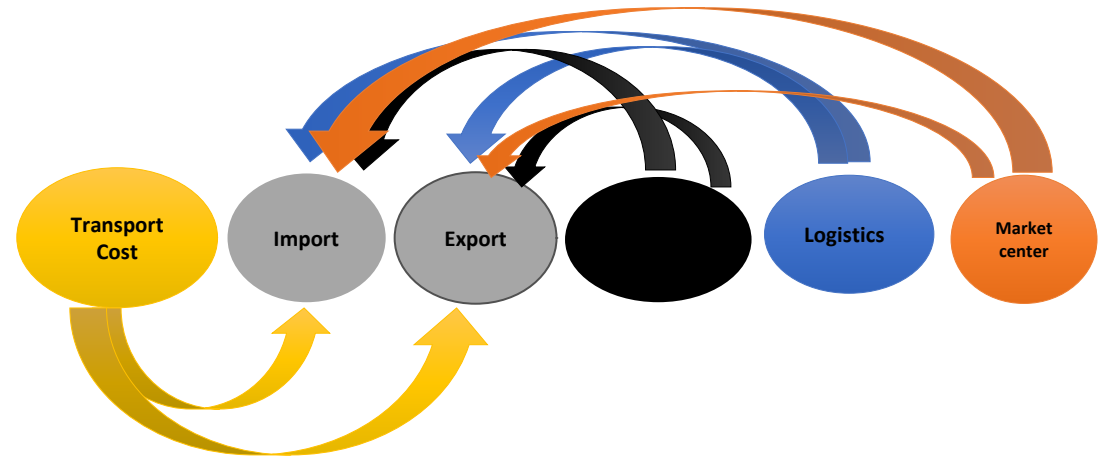

Figure 3. Interdependency among sub-criteria.

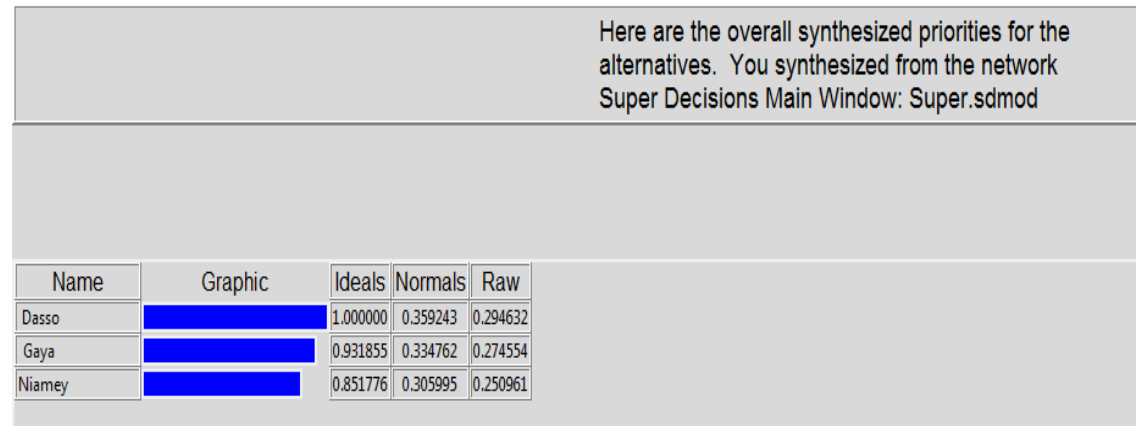

Figure 4. Overall synthesized priorities for the alternatives.

Based on the above objectives Dosso is the best alternative as shown in this analysis. The features of Dosso endorse the achievement of the said objectives according to the ranking based on the responses from the experts on the criteria, sub-criteria and the interdependency among them. Dosso is $136 \mathrm{~km}$ from Niamey on the Cotonou corridor which is a major transiting corridor from the port of Cotonou to Niger. It is also $462 \mathrm{~km}$ from the rail head at Parakou which creates a high degree of proximity compared to the other alternatives. This establishes a faster, reliable and cost effective connectivity between the seaport and the hinterland. The dominant port for Niger is Cotonou, which is the closest access to the sea from Niger, despite the operational problems of the railway link through Parakou.

Moreover, the selected area is a Greenfield development at the junction of the main routes to Cotonou and also to Zinder which is the second largest city in Niger. The out-of-town nature of the area will be a major contributing factor to cost reduction. 
While the objective of the dry port is consistent with typical role of such facilities, it is apparent that the recommended location is the most ideal location. Researchers have shown that the majority of cargo that move along the Cotonou transport corridor is destined for Niamey which might make it the ideal location for the facility. However, the pair-wise comparison of the expert responses demonstrated that demand is not the only important criteria to decide the location of the dry port, but rather cost and proximity as well. The distance between Cotonou sea port and Niamey is $1036 \mathrm{~km}$, while Dosso is $896 \mathrm{~km}$ from this sea port. Since transport cost is a function of distance, transport cost is a major impediment to landlocked countries in unlocking their international trade potential, hence the Dosso location will help to reduce cost resulting to a significant increase in the country's trading capacity.

\section{Conclusion}

Selecting a suitable location for the construction of a dry port facility is one of the crucial activities in dry port development. In this work, ANP model was used to calculate the relative weights of the criteria used. Super Decision software was used to select the optimal location for a dry port facility in Niger. Fifteen responses on a 22-questions' questionnaire were analyzed to give the required weights on criteria used in this evaluation. This was done through scores from a selected group of experts that comprised of operators, users and community representatives. The CR of the comparison matrices from each of the fifteen experts, were all below 0.1 , indicating a consistent trend in the responses. The alternatives used in this work were the proposed three locations for the construction of the dry port facility. From the analysis, Dosso was ranked as the most suitable location for the dry port facility with a total ratio of 0.2946 , a normalized value of 0.3592 and an ideal value of 1.0000. Gaya was ranked as the second suitable location for the dry port facility with a total value of 0.2746 , a normalized value of 0.3348 and an ideal value of 0.9319 , while Niamey was ranked third with a total of 0.2510 , a normalized value of 0.3060 and an ideal value of 0.8518 . This work also serves to confirm the selection of Dosso as a suitable location for the construction of a dry port. The construction of this facility commenced in 2010 under the public private partnership development model. This paper serves to provide pioneering steps towards finding the relevant location for dry port construction in Niger and prompting a research interest on dry ports especially in the West African countries, which have suffered high logistical cost for quite some time, consequently slowing eating into the revenues that could be used to improve the livelihood of the citizens. The findings are of relevance to policy makers involved in urban planning and port planning in landlocked countries like Niger. Potential areas of further research include: the challenges encountered in the dry port development at Dosso and public private partnership in dry port development-a case study of the Dosso dry port development. In addition, the influence that Dosso dry port would bring to the com- 
petitiveness of the seaports along the West African coastline could be another potential area of future research.

\section{Conflicts of Interest}

The authors declare no conflicts of interest regarding the publication of this paper.

\section{References}

[1] World Bank (2016) Data. https://data.worldbank.org/country/niger

[2] World Bank (2010) Connecting Landlocked Developing Countries to Markets. Trade Corridors in the 21st Century.

[3] World Bank, IFC (2018) Public-Private Partnerships 2121 Pennsylvania Ave. NW Washington DC.

[4] Cal MacWilliam, D. (2013) Policy Note No. 39. http://www.worldbank.org/afr/trade

[5] Woxenius, J., Roso, V. and Lumsden, K. (2004) The Dry Port Concept-Connecting Seaports with Their Hinterland by Rail. Proceedings of the 1 st International Conference on Logistics Strategy for Ports, Dalian, 22-26 September 2004, 305-319.

[6] Roso, V., Woxenius, J. and Lumsden, K. (2009) The Dry Port Concept: Connecting Container Seaports with the Hinterland. Journal of Transport Geography, 17, 381-398. https://doi.org/10.1016/j.jtrangeo.2008.10.008

[7] Henttu, V., Lättiläl, L. and Hilmola, O.-P. (2010) Financial and Environmental Impacts of a Dry Port to Support Two Major Finnish Sea Ports. Research Report 224, Lappeenranta University of Technology.

[8] vanDyck and Domfeh (2017) Gataway Port Selection Based on Inland Transport Cost and Performance Metrics in West Africa. International Journal of Economics, Commerce and Management United Kingdom, 5, 589-608.

[9] Ng, A.K.Y. and Gujar, G.C. (2009) The Spatial Characteristics of Dry Ports in India. Transport and Communications Bulletin for Asia and the Pacific, 78, 102-111.

[10] Abdoulkarim, H.T., Fatouma, S.H. and Munyao, E.M. (2019) Dry Ports in China and West Africa: A Comparative Study. American Journal of Industrial and Business Management, 9, 1-17.

[11] Saaty, T.L. (1996) The Analytic Network Process: Decision Making with Dependence and Feedback. RWS Publications, Pittsburgh.

[12] Saaty, T. (1980) The Analytic Hierarchy Process: Planning, Priority Setting, Resource Allocation. McGraw-Hill, New York.

[13] Saaty, T. (2001) Decision Making with Dependence and Feedback the Analytic Network Process. RWS Publications, Pittsburgh.

[14] Saaty, T. (2008) Decision Making with the Analytic Hierarchy Process. International Journal of Services Sciences, 1, 83-98. https://doi.org/10.1504/IJSSCI.2008.017590

[15] Jin, W.L. and Soung, H.K. (2000) Using Analytic Network Process and Goal Programming for Interdependent Information System Project Selection. Computers \& Operations Research, 27, 367-382. https://doi.org/10.1016/S0305-0548(99)00057-X

[16] Eddie, W., Cheng, L. and Li, H. (2004) Contractor Selection Using the Analytic Network Process. Construction Management and Economics, 22, 1021-1032. https://doi.org/10.1080/0144619042000202852

[17] Poonikom, K., Chansa-Ngavej, C. and O'Brien, C. (2003) A Framework for Univer- 
sities-Selection Decision Using the Analytic Network Process (ANP). Proceedings of the 7 th International Symposium on the Analytic Hierarchy Process, Bali, 7-9 August 2003, 403-416.

[18] Sanjay, J. and Ravi, S. (2007) Selection of Logistics Service Provider: An Analytic Network Process (ANP) Approach. The International Journal of Management Science, 35, 275-287.

[19] Saaty, T. (2001) Decision Making in Complex Environments. The Analytic Network Process for Decision Making with Dependence and Feedback, University of Pittsburgh, Pittsburgh.

[20] Saaty, T. (2001) Decision on National Missile Defense Program. The 6th International Symposium on the AHP, Bern, 2-4 August 2001, 365-382. 